\title{
"The impact of external auditor size on the relationship between audit committee effectiveness and earnings management"
}

\begin{tabular}{|c|c|}
\hline \multirow{3}{*}{ AUTHORS } & Mohammed Ibrahim Idris (D https://orcid.org/0000-0003-4966-7941 \\
\hline & Yousef Ibrahim Abu Siam iD https://orcid.org/0000-0002-1316-1677 \\
\hline & Ahmad Lutfi Ahmad iD https://orcid.org/0000-0003-0786-6264 \\
\hline ARTICLE INFO & $\begin{array}{l}\text { Mohammed Ibrahim Idris, Yousef Ibrahim Abu Siam and Ahmad Lutfi Ahmad } \\
\text { (2018). The impact of external auditor size on the relationship between audit } \\
\text { committee effectiveness and earnings management. Investment Management } \\
\text { and Financial Innovations, 15(3), 122-130. doi:10.21511/imfi.15(3).2018.10 }\end{array}$ \\
\hline DOI & http://dx.doi.org/10.21511/imfi.15(3).2018.10 \\
\hline RELEASED ON & Friday, 27 July 2018 \\
\hline RECEIVED ON & Tuesday, 05 December 2017 \\
\hline \multirow[t]{2}{*}{ ACCEPTED ON } & Wednesday, 18 July 2018 \\
\hline & $(\mathrm{cc})$ EY \\
\hline LICENSE & $\begin{array}{l}\text { This work is licensed under a Creative Commons Attribution } 4.0 \text { International } \\
\text { License }\end{array}$ \\
\hline JOURNAL & "Investment Management and Financial Innovations" \\
\hline ISSN PRINT & $1810-4967$ \\
\hline ISSN ONLINE & $1812-9358$ \\
\hline PUBLISHER & LLC "Consulting Publishing Company "Business Perspectives" \\
\hline FOUNDER & LLC "Consulting Publishing Company "Business Perspectives" \\
\hline
\end{tabular}

NUMBER OF REFERENCES

39

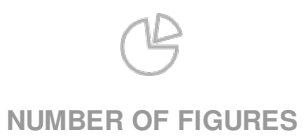

0
=:-:

NUMBER OF TABLES

2

(C) The author(s) 2022. This publication is an open access article. 


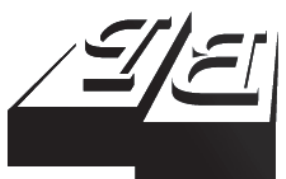

BUSINESS PERSPECTIVES

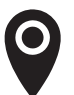

LLC "CPC "Business Perspectives" Hryhorii Skovoroda lane, 10, Sumy, 40022, Ukraine

www.businessperspectives.org

Received on: $5^{\text {th }}$ of December, 2017 Accepted on: $18^{\text {th }}$ of July, 2018

c) Mohammed Ibrahim Idris, Yousef Ibrahim Abu Siam, Ahmad Lutfi Ahmad, 2018

Mohammed Ibrahim Idris, Assistant Professor, Accounting Department, Faculty of Business, Applied Science Private University, Jordan.

Yousef Ibrahim Abu Siam, Assistant Professor, Accounting Department, Faculty of Business, Applied Science Private University, Jordan.

Ahmad Lutfi Ahmad, Assistant Professor, Accounting Department, School of Business, The University of Jordan, Jordan.

\section{(ㄷ) (1)}

This is an Open Access article, distributed under the terms of the Creative Commons Attribution 4.0 International license, which permits unrestricted re-use, distribution, and reproduction in any medium, provided the original work is properly cited.
Mohammed Ibrahim Idris (Jordan), Yousef Ibrahim Abu Siam (Jordan), Ahmad Lutfi Ahmad (Jordan)

\section{THE IMPACT OF EXTERNAL AUDITOR SIZE ON THE RELATIONSHIP BETWEEN AUDIT COMMITTEE EFFECTIVENESS AND EARNINGS MANAGEMENT}

\begin{abstract}
This research aims to explore new evidence on the nature of the relationship between the effectiveness of audit committee and earnings management in one of the emerging economies, Jordan. In addition, it investigates how external auditor size might moderate this relationship. For this purpose, a panel data consisting of 64 industrial firms listed on Amman Stock Exchange (ASE) is used, covering the period between 2009 and 2014. An index consisting of four characteristics is developed to measure the effectiveness of audit committee, namely audit committee independence, size, meetings and financial expertise. Results show that audit committee effectiveness has a significant and negative impact on earnings management. Moreover, a positive interaction effect of external auditor size and audit committee effectiveness on earnings management is found, which is supportive of the substitute relationship between the external auditor size and effective audit committee in reducing earnings management. Policy makers and professional accounting bodies in Jordan might benefit from these results, as they show that legislative reforms can motivate firms to adopt good governance practices to mitigate earnings management.
\end{abstract}

\section{Keywords}

audit committee effectiveness, external audit, earnings management, Jordan

\section{JEL Classification $\quad \mathrm{M} 41, \mathrm{M} 42$}

\section{INTRODUCTION}

Corporate governance (hereafter, CG) has developed a number of control mechanisms considering maximizing stakeholders' interests. These mechanisms are numerous, yet the audit committee (hereafter, AC) and external audit (hereafter, EA) remain the most appealing in enhancing the quality of financial reports (Cohen et al., 2004). Moreover, both of ACs and EAs have the ability to mitigate opportunities available to managements for earnings manipulation (Bradbury et al., 2006).

As regards the effectiveness of the AC mechanism, Mangena and Pike (2005) state that AC characteristics, for instance, independence, degree of financial expertise, size and the number and nature of meetings are a measurement of its effectiveness. A considerable research has tested the influence of the individual characteristics of AC mechanism on managed earnings. This method has been criticized in recent studies for its inability to represent the effectiveness of AC. According to DeZoort et al. (2002), the AC effectiveness framework could improve significantly if AC characteristics are considered together. Following the same rationale, the current study examines AC characteristics (independence, size, frequent meetings and financial expertise) as a com- 
posite measure to capture their combined influence on both the practical and the theoretical sides of earnings management in the emerging market of Jordan.

EA is thought of as another vital monitoring mechanism that helps in aligning the interests of shareholders and managers. This would consequently reduce the likelihood for management opportunistic behavior. For instance, Frankel et al. (2002) provide evidence of the adverse relationship between the monitoring quality of a high quality EA and earnings management. Yet, for this mechanism to act properly on this matter, EA must provide high quality audits. Several researchers state that most previous research has mainly proxied audit quality using auditor size (e.g. Francis, 2004; Ronen \& Yaari, 2008). This auditor differentiation is based on the argument of DeAngelo (1981) who proposes that audit firm size is an appropriate proxy for audit quality, because no single client is important to large auditors, as they have superior reputation to lose should they behave opportunistically. Using this reasoning, this study uses auditor size to proxy for external audit quality.

Moreover, while the aforementioned CG mechanisms aim to ensure the quality of the process of financial reporting, the relationship between $\mathrm{AC}$ effectiveness and EA quality has been considered as controversial one. Existing literature emphasizes two possible approaches in an attempt to clarify how AC effectiveness and EA quality interact: ACs and EAs can be considered as either substitutes or complements for each other (Hay et al., 2008). The first perspective entails that these CG mechanisms substitute each other given that internal control mechanisms react to changes in external control and vice versa. Thus, a negative effect is anticipated between the $\mathrm{AC}$ and the EA. The second perspective acknowledges that internal governance mechanisms are required for the external mechanisms to act, resulting in a complementary relationship between these mechanisms. Hence, a positive relationship is expected between AC and EA (Adjaoud et al., 2007). Therefore, the current study attempts to extend prior literature through examining both approaches through the measurement of the moderating influence of EA quality on the relationship between AC effectiveness and earnings management.

Accordingly, the current study will be organized as follows: section 1 is devoted to previous literature and the theoretical framework and hypotheses, whereas section 2 deals with the methodological approach, section 3 is devoted to the discussion of results and finally last section presents the conclusions.

\section{RESEARCH BACKGROUND}

\subsection{Audit committee effectiveness and earnings management}

Monitoring and controlling the process of financial reporting are often considered the main duties of boards of directors. However, this role is often delegated to a subcommittee called the AC. The main role of the AC stems from the internal CG of firms, because it is about monitoring and establishing the financial reporting process in order to deliver appropriate and highly credible information for stakeholders (McMullen, 1996). According to the agency theory, the $\mathrm{AC}$ is an effective monitoring mechanism conditional on having independent directors, members with financial expertise, sufficient directors, and frequent meetings (Carcello et al., 2006).
Previous literature has investigated the relationship between the different features that reflect the AC effectiveness and various practices of earnings management. For instance, Klein (2002) and Soliman and Ragab (2014) examine whether an increasing the independent directors percentages on the $\mathrm{AC}$ will decrease the amount of abnormal accruals. Kent et al. (2010) and Metawee (2013) measure the relationship between the directors' number in the $\mathrm{AC}$ and the magnitude of managed earnings. Lin and Hwang (2010) and Soliman and Ragab (2014) test the effect of meetings number carried out by the $\mathrm{AC}$ on the practice of earnings management. Lei (2008) and Habbash et al. (2013) investigate the contribution of financial expertise on the AC in constraining earnings management. Although a negative effect is hypothesized among the AC characteristics and opportunistic earnings management behavior, the findings are to some extent mixed. 
It should be noted that these studies examine relationships on an individual basis. The results from previous research that used the effectiveness of a single governance mechanism might be ambiguous by proving that the effect of some single mechanisms on corporate performance disappeared in the combined measure (Agrawal \& Knoeber, 1996). More recently, the function of governance mechanisms can be better as a group compared with the stand-alone mechanism (Ward et al., 2009). Consequently, several studies proxy for the AC mechanism in an overall composite measure, Dhaliwal et al. (2007) find the strength of AC results in higher accruals quality through using three commonly used characteristics, namely $\mathrm{AC}$ size, $\mathrm{AC}$ independence, and $\mathrm{AC}$ meetings in one measure. According to Jenkins (2002), there are four mechanisms to measure the effectiveness of $\mathrm{AC}$, and there is a negative relation between $\mathrm{AC}$ effectiveness and discretionary accruals. In the Australian context, a study by Kent et al. (2010) examines the individual AC variables: a composite variable is calculated to measure $\mathrm{AC}$ quality that involved four features of $\mathrm{AC}$ (independence, size, meeting, and financial expertise). Their findings indicate that higher innate accruals quality is associated with active AC. In the Jordanian context, a recent research conducted by Abbadi et al. (2016) uses an index for AC characteristics and investigates its effectiveness in deterring earnings management. Their results provide strong evidence that the CG quality negatively affects earnings management. Nevertheless, apart from being the only research found to have established an index for AC characteristics, its index only includes the existence of AC, number of meetings, and financial expertise, and thus excludes ACs independence and size from the index. This might be explained, at least partially, by the low level of non-financial information reported by firms listed on ASE.

Since the effectiveness of $\mathrm{AC}$ is considered one of the most crucial elements in the mechanisms of internal CG, and depends on its characteristics, it could be argued that AC that have a higher score for its effectiveness have more ability to monitor the management, protect shareholders' interests and help to restrict earnings management practices. Hence, this study uses a composite measure for AC effectiveness as proposed by Jenkins (2002) and Kent et al. (2010) and seeks to explore the effective- ness of AC characteristics in deterring practices of earnings management in Jordanian firms. As such, this research provides a more comprehensive index for AC effectiveness and measures its effect on accruals earnings management.

On this basis, firms with high quality ACs in Jordan are expected to have enhanced high quality financial reporting systems. Thus, the following hypothesis is developed:

\section{H1: There is an adverse relationship between audit committee effectiveness and earnings management.}

\subsection{Impact of Big 4 audit firms on the relationship between $A C$ effectiveness and EM}

Early research conducted by Eichenseher and Shields (1985) and Menon and Williams (1994) documents significant effect of the audit firm size and the formation of AC. The researchers conclude that firms hiring big audit firms are more exposed to voluntarily form an AC. This interaction between ACs and EAs can probably provide external stakeholders with financial information of high quality (Mitchell et al., 2008). However, such interaction raises the issue of the substitution and complementary contrasting approaches to these two monitoring mechanisms. That is, previous research introduces two approaches to justify the relation between external audit quality and AC effectiveness: ACs and EAs are thought of as either substitutes or complements to each other.

On the one hand, the substitute approach demonstrates that the AC effectiveness is adversely linked to audit quality. This is since either ACs or EAs monitoring mechanisms is likely to be adequate in guaranteeing high quality external reporting. Evidence supporting the substitution effect includes Cohen et al. (2000) who examine the effect of the strength of companies' corporate governance structure on audit planning judgments. They find that audit planning judgments are more favorable for companies with ACs having sufficient technical experience and resources. Lee et al. (2004) provide additional evidence through investigating resignations of EAs. They find EAs seem to quit more often should companies have ineffec- 
tive independent $\mathrm{AC}$, indicating that $\mathrm{AC}$ effectiveness affects EA's audit risk assessment and motivation to proceed with auditing tasks.

On the other hand, the complement approach implies a positive relation between audit quality and $\mathrm{AC}$ effectiveness. This is because directors of effective ACs are likely to require the assurance presented by EAs (Hay et al., 2008). For example, Abbott et al. (2000) investigate the relationship between audit firm size and AC effectiveness and realize that companies with effective ACs are inclined to select the (then) Big 6 auditors when replacing auditors. Supportive evidence is provided by Goodwin and Seow (2002) who explore the impact of effective ACs in improving the quality of auditing in Singapore. They report that strong ACs have a significant effect on perceived audit effectiveness.

Within the field of earnings management, research concerning which approach is more relevant to explaining the relation between audit quality and AC effectiveness is inconclusive so far. That is, the research on the substitute versus complementary approaches and earnings management is very limited. Of the few available studies, Kheirollah (2013) documents a heterogeneous effect of governance bundles on earnings management policies, imperfect substitutability and complementarily, as well as diminishing marginal rate of substitution between mechanisms within governance bundles in relation to earnings management policies. On the contrary, Zgarni et al. (2016) provides evidence supportive of the substitution effect between auditor type and effective $\mathrm{AC}$ in reducing the magnitude of managed earnings before the enforcement of law number 2005-96 in Tunisia. This law, however, relates to Tunisian firms making public offerings. In such samples, it could be argued that while managements would resort to income increasing earnings management to convey value relevant information under the blessings of boards of directors, Big 4 auditors would act conservatively through deterring earnings management practices in order to keep their reputations intact. To overcome such limitations, this research extends that of Zgarni et al. (2016) through the inclusion of all industrial firms listed on ASE rather than limiting the sample to pre- and post-initial public offerings. Therefore, this research takes in- to consideration the effect of auditor size on the relationship between $\mathrm{AC}$ effectiveness and earnings management to provide insight on whether Big 4 auditors would act as substitution to the AC effectiveness or complement.

In addition, the novelty of this research lies in application of a moderation approach to determine which approach prevails in relation to the field of earnings management. That is, while Zgarni et al. (2016) consider AC effectiveness as a mediator to the relationship between external audit quality and earnings management, this research tests the moderation effect of external audit quality on the relation between the AC effectiveness and earnings management.

The justification for this first attempt to apply the moderation approach among the research variables is that previous literature document an adverse relationship between AC effectiveness and earnings management (e.g. Kent et al., 2010; Habbash et al., 2013), and another adverse relationship between external audit quality and earnings management (e.g. Lin \& Hwang, 2010; Inaam \& Khmoussi, 2012). Such relationships are considered as prerequisites for testing the moderating effect of external audit quality on the relation between $\mathrm{AC}$ effectiveness and earnings management. Hence, if the interaction between external audit quality and AC effectiveness was found positive (negative) and statistically significant, then it would indicate a substitution (complementary) effect.

On this basis, Big 4 auditors are expected to act as a moderator to the $\mathrm{AC}$ effectiveness in restricting opportunistic practices by earnings management. Thus, the following hypothesis is proposed:

\section{H2: $\quad$ Big 4 audit firms moderate the relationship between AC effectiveness and EM.}

\section{METHODOLOGY}

\subsection{Population and sample selection}

The population of this study consists of industrial firms registered on ASE during the period 20092014. The sample includes all industrial firms that have available data related to CG and earnings man- 
agement. The total number of industrial firms is 81 , 64 of which are used in the study. Of the 17 excluded firms, 11 firms are omitted, because they represent the mining industry ${ }^{1}$, and 6 firms are omitted due to data unavailability regarding CG information and/ or financial information for the test period.

As regards data collection, ASE website (www.ase. com.jo) provides all financial information about listed industrial firms that are needed for both the estimation of discretionary accruals and hypotheses testing. However, the annual reports of research sample do not provide sufficient information about CG variables. Due to data unavailability, this study follows Gabrielsen et al.'s (2002) approach to collect the needed nonfinancial data. That is, a questionnaire is specifically designed and distributed for the sole purpose of gathering data that are not available on ASE website.

\subsection{Empirical models}

To facilitate testing hypotheses of this study, two regression models are used. The first model is designed to examine the impact of AC effectiveness on EM. The second model is designed to measure the effect of Big 4 auditors on the relationship bee tween AC effectiveness and EM through the inclusion of an interaction term between AC effectiveness and Big 4 audit firms.

Model (1):

$$
\begin{aligned}
& D A_{i t}=a_{0}+\beta_{1} A C E_{-} \text {Score }_{i t}+\beta_{2} \text { SIZE }_{i t}+ \\
& +\beta_{3} L E V_{i t}+\beta_{4} \text { BSIZE }_{i t}+\varepsilon_{i t} .
\end{aligned}
$$

Model (2):

$$
\begin{aligned}
& D A_{i t}=a_{0}+\beta_{1} A C E_{-} \text {Score }_{i t}+\beta_{2} \text { SIZE }_{i t}+ \\
& +\beta_{3} L E V_{i t}+\beta_{4} \text { BSIZE }_{i t}+\beta_{5} B I G 4_{i t}+ \\
& +\beta_{6} A C E_{-} \text {Score }_{i t} \cdot B I G 4_{i t}+\varepsilon_{i t} .
\end{aligned}
$$

where

\section{Dependent variable}

$D A$ - the discretionary accruals estimated via the Kothari et al. (2005) model.

\section{Independent variables}

$A C E$ _Score - AC effectiveness, a composite score measuring the effectiveness of audit committee ranging between 0 and 4 with 0 indicating the lowest effectiveness and 4 the highest effectiveness. The score is formed by aggregating the composite scores obtained from four $A C$ constructs, independence, size, meetings, and financial expertise; $A C I N D$ - $A C$ independence is coded " 1 " if the percentage of independent directors on the committee is above the sample median and "0" otherwise; ACSIZE - AC size is coded "1" if the number of audit committee is above the sample median, and " 0 " otherwise; ACMEET - AC meeting is coded " 1 " if the number of $A C$ meetings is above the sample median and " 0 " otherwise; $A C F I N$ - AC financial expertise is coded " 1 " if the proportion of financial experts on the committee is above the sample median and " 0 " otherwise; $B I G 4$ - a dummy variable that takes the value of 1 if the firm is being audited by one of the $B I G 4$ auditors in Jordan, and 0 otherwise; $A C E \quad$ Score $B I G 4$ - interaction term between $A C E_{-}$Score and BIG4.

\section{Control variables}

SIZE - the natural logarithm of total assets; $L E V$ - total liabilities divided by total assets; $B S I Z E$ - total number of directors serving on the board of directors.

\section{Estimation of discretionary accruals}

In line with the previous studies such as Klein (2002) and Alves (2012), the current study uses the magnitude of discretionary accruals (DA) as a proxy for the EM through using Kothari et al.'s (2005) model, because this model proved to be more robust in detecting earnings management in recent years. This model is as follows:

$$
\begin{aligned}
& \frac{T A C_{i t}}{T A_{i t}}=\alpha\left(\frac{1}{T A_{i t}-1}\right)+\beta_{1}\left(\frac{\Delta R E V_{i t}-\Delta R E C_{i t}}{T A_{i t}-1}\right)+ \\
& +\beta_{2}\left(\frac{P P E_{i t}}{T A_{i t}-1}\right)+\beta_{3} R O A_{i t}-1+\varepsilon_{i t},
\end{aligned}
$$

1 Idris (2012) reports that the mining sector cause the normality of residuals assumption to be violated because of the heterogeneity of accounts, operations, and size between mining companies and the rest of industrial companies in Jordan. 
Table 1. Descriptive statistics

\begin{tabular}{l|c|c|c|c}
\hline \multicolumn{1}{c}{ Variable } & Mean & Standard deviation & Maximum & Minimum \\
\hline DA & 0.053 & 0.038 & 0.358 & 0.001 \\
ACE_Score & 2.825 & 1.296 & 4 & 0 \\
BIG4 & 0.546 & 0.498 & 1 & 0 \\
SIZE & 7.223 & 0.616 & 9.088 & 5.742 \\
LEV & 0.358 & 0.239 & 1.071 & 0.001 \\
BSIZE & 8.127 & 1.960 & 13 & 5 \\
\hline
\end{tabular}

Note: Total number of observations for all variables is 384; $D A$ (earnings management) - absolute value of discretionary accruals estimated by Kothari et al. (2005) model; $A C E \_S c o r e$ ( $A C$ effectiveness) - score for effectiveness of the $A C$, which can range from $0-4 ; B I G 4$ (audit firm size) - equals "1" if the firm is audited by a BIG 4, and " 0 " otherwise; SIZE (firm size) - natural logarithm of total assets; $L E V$ (leverage) - total liabilities scaled by total assets; BSIZE (board size) - total number of directors on the board.

where $T A C_{i t}$ - total accruals in year $t$ for firm $i, T A_{i t-1}$ - total assets in year $t-1$ for firm $i$, $\triangle R E V_{i t}$ - change in sales revenues in year $t$ from year $t-1$ for firm $i, \Delta R E C_{i t}$ - change in accounts receivables in year $t$ from year $t-1$ for firm $i, P P E_{i t}$ - property, plant and equipment at end in the year $t$ for firm $i, R O A_{i t-1}$ - return of assets in year $\mathrm{t}$ from year $t-1$ for firm $i$ (net income divided by lagged total assets), $\alpha, \beta_{1}, \beta_{2}$, $\beta_{3}$ - estimated parameters, $\varepsilon_{i t}$ - the residual.

\section{RESULTS AND DISCUSSION}

\subsection{Descriptive statistics}

Table 1 demonstrates the descriptive statistics of variables which have been used in this study for 384 firm-year observations and covering the period from 2009 to 2014. According to this table, the average absolute value of discretionary accruals has a mean value of 0.053 , with the (minimum and maximum) values of 0.001 and 0.358 , respectively. This indicates that managers of Jordanian firms tend to manage firm's earnings. Furthermore, Table 1 exhibits that the average score for the effectiveness of the AC (ACE_Score) is 2.825 with a standard deviation of 1.296 and the maximum and minimum score are 4 and 0 , respectively. This result signifies that firms with more effective ACs can reduce agency conflicts by enhancing the effectiveness of monitoring and provide credible financial reports and, thus, mitigate the level of managed earnings. Table 1 also demonstrates that $54.6 \%$ of the sample firms audited by Big 4 audit firms as opposed to only $45.4 \%$ that are audited by non-Big 4 auditors.

In terms of control variables, it appears from Table 1 that the mean of firm size (SIZE) is 7.223 with both (minimum and maximum) values of 5.742 and 9.088 respectively, while the leverage (LEV) mean is 0.358 with both (minimum and maximum) values of 1.071 and 0.001 , respectively. Moreover, average board size (BSIZE) of the sample is 8.127 , with a standard deviation of 1.960 , and a maximum value of 13 and a minimum value of 5 . This result confirm that the majority of industrial listed firms meet the terms with the recommendations of the code of CG, which states that every reputable firm must determine the board of directors number, hence, this number is not more than thirteen and not less than five.

\subsection{Main empirical results}

Table 2 illustrates that $A C E \_S c o r e$ has a negative significant relationship with earnings management supporting the first hypothesis of the research. This finding supports the agency theory prediction, which posits that an effective $A C$ leads to improved financial reporting quality. It is also worth noting that this result is similar to that of Abbadi et al. (2016) in spite of the differences in the characteristics included in the indices of $A C$ effectiveness. Additionally, the results suggest that $A C s$ is more able to constrain earnings management when all effective characteristics are present simultaneously. This means that ACs that consist of a minimum of three members, consist of independent directors, include no less than one expert in finance, and meet no less than three times a year, mitigate earnings management more than ACs that do not possess all four characteristics. Therefore, such index seems to be much influential more measurement of effectiveness than any of the separate variables. As such, effective $A C$ s in Jordan play a vital role in the improvement of cor- 
Table 2. Regression analysis of earning management, audit committee effectiveness and Big 4 audit firms

\begin{tabular}{|c|c|c|c|c|}
\hline \multirow{2}{*}{ Variable } & \multicolumn{2}{|c|}{ Model (1) } & \multicolumn{2}{|c|}{ Model (2) } \\
\hline & Coef. & t-stat & Coef. & t-stat \\
\hline Intercept & $0.174 * * *$ & 1.30 & $0.185^{* * *}$ & 2.72 \\
\hline ACE_Score & $-.016^{* * *}$ & -10.14 & $-0.021^{* * *}$ & -9.09 \\
\hline BIG4 & - & - & $-0.012^{* * *}$ & -2.46 \\
\hline$A C E_{-}$Score $\cdot B I G 4$ & - & - & $0.014^{* * *}$ & 5.93 \\
\hline SIZE & -0.021 & -1.15 & $-0.018^{* * *}$ & -2.29 \\
\hline LEV & 0.015 & 0.73 & 0.018 & 1.25 \\
\hline BSIZE & $0.009^{* * *}$ & 4.05 & $0.008^{* * *}$ & 7.00 \\
\hline Adj.R2 & 0.479 & - & 0.510 & - \\
\hline Obs & 384 & - & 384 & - \\
\hline F-stat & 9.63 & - & 11.65 & - \\
\hline
\end{tabular}

Note: ${ }^{* *}$ indicate significance at $1 \%$. Refer to Table 1 for description of variables details except for ACE_Score $\cdot B I G 4$, which equals the interaction between audit committee effectiveness and $B I G 4$ auditors.

porate financial reporting through minimizing the level of opportunistic earnings management practices.

Table 2 also demonstrates the results of the impact of $E A$ size on $A C$ effectiveness in constraining earnings management. The results of Model 2 show that the coefficient on $A C$ effectiveness remains negative and significant even after the inclusion of the interaction variable. The significant and positive coefficient on the interaction of $A C$ effectiveness and $E A$ proposes that BIG4 auditors do act as a moderator to the effectiveness of the $A C$ in constraining opportunistic earnings management practices in Jordan. Thus, the results are consistent with the second research hypothesis. This indicates that $E A$ could be a substitute rather than a complement to $A C$ effectiveness in reducing discretionary accruals. A plausible interpretation for this result is that when a firm has strong internal control mechanisms, EAs reduce their efforts. Thus, Big 4 audit firms are less efficient in constraining earnings management when the $A C$ is effective.

\section{CONCLUSION}

The key purpose of this study is to examine and explore the $A C$ effectiveness in mitigating earnings management in the Jordanian setting. In addition, the study tests for the moderating effect of $E A$ 's size on the association between the score of $A C$ effectiveness and earnings management. The results of this study found that earnings management is negatively associated with $A C$ effectiveness as a composite measure. This is consistent with agency theory which posits that enhancing the effectiveness of the internal corporate mechanisms, such as $A C$, mitigates agency conflicts and hence should deter opportunistic earnings management practices.

Furthermore, this study provides evidence that $A C$ effectiveness is significantly and negatively associated with earnings management. When controlling for the moderating effect of $E A$ 's size, the association between $A C$ effectiveness and earnings management has weakened but remained significant. This means that $E A$ is less effective in reducing earnings management when the $A C$ is effective. Therefore, it could be argued that high audit quality is more effective in improving the quality of financial information in contexts with weak legal regulatory systems than in contexts with strong legal regulatory systems, because high audit quality might function as a substitute to internal $C G$ mechanisms.

The first limitation of the study arises from the mere use of Jordanian data. The findings of the study are recommended to be cautiously generalized to contexts with diverse economic conditions and regulations. The study sample may represent another limitation, as it only considers listed industrial firms. 
Thus, the generalization of the results to other sectors, such as the service and financial sectors, may be constrained.

Based on the conclusions above, the significance of the study lies in its implications concerning the interaction between various $C G$ mechanisms in Jordan. The results might aid regulators to introduce remedies considered necessary to enhance good $C G$ practices in the country. For instance, introducing regulations, similar to those of the US, to strictly govern $A C s$ characteristics and holding directors of $A C s$ liable for the quality of financial reporting.

\section{ACKNOWLEDGEMENT}

The author is grateful to the Applied Science Private University for the partial financial support granted to this research project.

\section{REFERENCES}

1. Abbadi, S. S., Hijazi, Q. F., \& AlRahahleh, A. S. (2016). Corporate governance quality and earnings management: Evidence from Jordan. Australasian Accounting Business \& Finance Journal, 10(2), 54. http:// dx.doi.org/10.14453/aabff.v10i2.4

2. Abbott, L. J., Park, Y., \& Parker, S. (2000). The effect of audit committee activity and independence on corporate fraud. Managerial Finance, 26(11), 55-67. https://doi. org/10.1108/03074350010766990

3. Adjaoud, F., Zeghal, D., \& Andaleeb, S. (2007). The effect of board's quality on performance: A study of Canadian firms. Corporate Governance: An International Review, 15(4), 623-635. https:// doi.org/10.1111/j.14678683.2007.00592.x

4. Agrawal, A., \& Knoeber, C. R. (1996). Firm performance and mechanisms to control agency problems between managers and shareholders. Journal of Financial and Quantitative Analysis, 31(3), 377-397.

5. Alves, S. M. G. (2012). Ownership structure and earnings management: Evidence from Portugal. Australasian Accounting Business and Finance Journal, 6(1), 57-74.

6. Amman Stock Exchange (2017). Retrieved from https://www.ase. com.jo
7. Bradbury, M. E., Mak, Y. T., \& Tan, S. M. (2006). Board characteristics, audit committee characteristics and abnormal accruals. Pacific Accounting Review, 18(2), 47-68.

8. Carcello, J. V., Hollingsworth, C. W., Klein, A., \& Neal, T. L. (2006). Audit committee financial expertise, competing corporate governance mechanisms, and earnings management. Competing Corporate Governance Mechanisms, and Earnings Management (February 2006).

9. Cohen, J., Krishnamoorthy, G., \& Wright, A. (2004). The corporate governance mosaic and financial reporting quality. Journal of Accounting Literature, 23, 87-152.

10. Cohen, J., Krishnamoorthy, G., \& Wright, A. M. (2002). Corporate governance and the audit process. Contemporary accounting research, 19(4), 573-594.

11. DeAngelo, L. E. (1981). Auditor Size and Audit Quality. Journal of Accounting and Economics, 3(3), 183-199.

12. DeZoort, F. T., Hermanson, D. R., Archambeault, D. S., \& Reed, S. A. (2002). Audit committee effectiveness: A synthesis of the empirical audit committee literature. Journal of Accounting Literature, 21(2002), 38-75.

13. Dhaliwal, D. S., Naiker, V., \& Navissi, F. (2007). Audit committee financial expertise, corporate governance, and accruals quality: An empirical analysis. Corporate Governance and Accruals Quality: An Empirical Analysis (May 2007).

14. Eichenseher, J. W., \& Shields, D. (1985). Corporate director liability and monitoring preferences. Journal of Accounting and Public Policy, 4(1), 13-31.

15. Francis, J. (2004). What Do We Know about Audit Quality? The British Accounting Review, 36(4), 345-184.

16. Frankel, R. M., Johnson, M. F., \& Nelson, K. K. (2002). The relation between auditors' fees for non-audit services and earnings management. The Accounting Review, 77(Suppl.), 71-105.

17. Gabrielsen, G., Gramlich, J. D., \& Plenborg, T. (2002). Managerial ownership, information content of earnings, and discretionary accruals in a Non-US setting. Journal of Business Finance \& Accounting, 29(7-8), 967-988. https://doi.org/10.1111/14685957.00457

18. Goodwin, J. \& Seow, J. L. (2002). The Influence of Corporate Governance Mechanisms on the Prevention and Detection of Control Weaknesses, Fraud and Error: The Perceptions of Auditors and Directors. Accounting \& Finance, 42, 195-233. 
19. Habbash, M., Sindezingue, C., \& Salama, A. (2013). The effect of audit committee characteristics on earnings management: Evidence from the UK. International Journal of Disclosure and Governance, 10(1), 13-38.

20. Hay, D., Knechel, W. R., \& Ling, H. (2008). Evidence on the impact of internal control and corporate governance on audit fees. International Journal of Auditing, 12(1), 9-24. https://doi.org/10.1111/j.10991123.2008.00367.x

21. Idris, M. I. I. (2012). The Impact of Ownership Structure and External Audit on Accruals and Real Activities Earnings Management in Jordan (Published $\mathrm{PhD}$ thesis, University of Gloucestershire, UK).

22. Inaam, Z., Khmoussi, H., \& Fatma, Z. (2012). Audit Quality and Earnings Management in the Tunisian Context. International Journal of Accounting and Financial Reporting, 2(2), 17. https://doi. org/10.5296/ijafr.v2i2.2065

23. Jenkins, G. J., \& Krawczyk, K. (2002). The relationship between non audit services and perceived auditor independence: Views of nonprofessional investors and auditors. Journal of Business and Economic Perspectives, 16, 25-36. Retrieved from https:// www.researchgate.net/publication/285036451_The_relationship_between_nonaudit_services_and_perceived_auditor_independence_Views_of_nonprofessional_investors_and_auditors

24. Kent, P., Routledge, J., \& Stewart, J. (2010). Innate and discretionary accruals quality and corporate governance. Accounting and Finance, 50(2), 171-195.

25. Kheirollah, A. (2013). Bundle of governance mechanisms; Industry regulation and corporate governance: Jointly substitutes and complements? (October 7, 2016). SSRN. http://dx.doi.org/10.2139/ ssrn. 2369380

26. Klein, A. (2002). Audit Committee, board of director characteristics, and earnings management. Journal of Accounting and Economics, 33(3), 375-401.
27. Kothari, S. P., Leone, A. J., \& Wasley, C. E. (2005). Performance matched discretionary accruals. Journal of Accounting and Economics, 39(1), 163-197.

28. Lee, H. Y., Mande, V., \& Ortman, R. (2004). The effect of audit committee and board of director independence on auditor resignation. Auditing: A Journal of Practice and Theory, 23(2), 131-146. https://doi.org/10.2308/ aud.2004.23.2.131

29. Lei, K. (2008). Earnings Management and Corporate Governance in the UK: The Role of the Board of Directors and Audit Committee. Doctoral dissertation, National University of Singapore, Singapore.

30. Lin, J. W., \& Hwang, M. I. (2010). Audit quality, corporate governance, and earnings management: A meta-analysis. International Journal of Auditing, 14(1), 57-77. https://doi.org/10.1111/j.10991123.2009.00403.x

31. Mangena, M., \& Pike, R. (2005). The effect of audit committee shareholding, financial expertise and size on interim financial disclosures. Accounting and Business Research, 35(4), 327-349. https://doi.org/10.1080/00014788.2 005.9729998

32. McMullen, D. A. (1996). Audit committee performance: An investigation of the consequences associated with audit committees. Auditing: Journal of Practice and Theory, 15(1), 87-103.

33. Menon, K., \& Williams, J. (1994). The use of audit committee for monitoring. Journal of Accounting and Public Policy, 13(2), 121-139.

34. Metawee, A. (2013 January). The relationship between characteristics of audit committee, board of directors and level of earning management: Evidence from Egypt. Journal of International Business and Finance, Plymouth Business School, UK. Retrieved from http:// www.academia.edu/4019360/ The_relationship_between_characteristics_of_audit_committee_board_of_directors_and_level_of_earning_management_Evidence_from_Egypt
35. Mitchell, V. Z., Singh, H., \& Singh, I. (2008). Association between independent audit committee members' human-resource features and underpricing. The case of Singapore IPOs from 1997-2006. Journal of Human Resource Costing \& Accounting, 12(3), 179-212.

36. Ronen, J., \& Yaari, V. (2008). Earnings Management: Emerging Insights in Theory, Practice, and Research (3rd ed.). New York: Springer.

37. Soliman, M. M., \& Ragab, A. A. (2014). Audit committee effectiveness, audit quality and earnings management: An empirical study of the listed companies in Egypt. Research Journal of Finance and Accounting, 5(2), 155-166. Retrieved from http://www.iiste.org/Journals/index.php/RJFA/article/view/10690

38. Ward, A. J., Brown, J. A., \& Rodriguez, D. (2009). Governance bundles, firm performance, and the substitutability and complementarily of governance mechanisms. Corporate Governance: An International Review, 17(5), 646-660. https:// doi.org/10.1111/j.14678683.2009.00766.x

39. Zgarni, I., Hlioui, K., Zehri, F. (2016). Effective audit committee, audit quality and earnings management: Evidence from Tunisia. Journal of Accounting in Emerging Economies, 6(2), 138-155. https://doi.org/10.1108/JAEE-092013-0048 